
УДК 37.016:614.8(477)

DOI: 10.31470/2518-7600-2019-6/2-134-150

\author{
MODERN PROBLEMS OF TEACHING SUBJECTS \\ RELATED TO HUMAN SECURITY IN WEST UKRAINE
}

\title{
СУЧАСНІ ПРОБЛЕМНІ ПИТАННЯ ВИКЛАДАННЯ ДИСЦИПЛІН, ПОВ'ЯЗАНИХ 3 БЕЗПЕКОЮ ЛЮДИНИ У ЗВО УКРАЇНИ
}

\author{
Андрій Литвин, \\ кандидат педагогічних наук, \\ викладач кафедри теорії та \\ методики професійної \\ підготовки, \\ Andrey10716@i.ua \\ https://orcid.org/0000-0003- \\ $1400-6510$ \\ ID: B-2142-2019 \\ ДВНЗ «Переяслав- \\ Хмельницький \\ державний педагогічний \\ університет \\ імені Григорія Сковороди», \\ вул. Сухомлинського, 30, \\ м. Переяслав-Хмельницький, \\ Київська обл., Україна, 08401
}

\author{
Andrii Lytvyn, \\ PhD (Pedagogics), lecturer of \\ the Department of theory and \\ methods of professional \\ training, \\ Andrey10716@i.ua \\ https://orcid.org/0000-0003- \\ $1400-6510$ \\ ID: B-2142-2019 \\ Pereiaslav-Khmelnytskyi \\ Hryhorii Skovoroda State \\ Pedagogical University, 30, \\ Sukhomlynsky Str., \\ Pereiaslav-Khmelnytskyi, \\ Kyiv region, Ukraine, 08401
}

\section{ABSTRACT}

The article deals with topical issues of teaching disciplines related to human security in higher education institutions. Defined what determines the effectiveness of the educational process at the security subjects to perform any task you need to send teachers to tackle contemporary problems of training in the safety of future teachers of vocational training. The complex of teaching methods that are appropriate to use in any type of training on life safety.

It is concluded that the cycle of disciplines "life Safety» as a system of ensuring and preserving life is the most important 
component of vocational education, and can be reformed and supplemented taking into account the specialization of higher education institutions or the direction of training of students, also in the preparation of specialists should not underestimate the role of Sciences related to safety, in the formation of professional skills of future specialists in all sectors. In addition, in the institution of higher education it is advisable to adhere to a step-by-step scheme of studying the cycle of security disciplines, and to have the highest priority, because security is an important component of human life, which is guaranteed by the Constitution of Ukraine. Possible ways of solving the problems are proposed.

In modern conditions of strengthening of integration processes with the European.

The Union, the introduction of the European system of continuing education programs of normative disciplines and relevant educational and professional programs should take into account the provisions of the perfect European system of legal acts on human security.

Therefore, considering the problems of teaching disciplines related to the safety of people in the process of training in the subjects of "Life Safety», "Fundamentals of labor protection» and "Civil protection" it is necessary to provide for the search for optimal forms and methods of educational process for the implementation of interdisciplinary connections and increase practical training on the basis of modern regulatory framework, the development of special technologies for the formation of professional competence of specialists in all areas, to improve the methods of training students in theoretical and practical components with the purposeful formation of their professional competence and to enhance the professional self-improvement of students, which contributes to their self-actualization, the formation of their professional needs, motives and motivations.

Key words: professional education, labor protection, methods, activity, students, specialists, technologies.

Постановка проблеми. Стратегія інтеграції України до Європейського Союзу передбачає реформування вітчизняного законодавства 3 метою наближення його до європейської 
системи права, зокрема, в галузі безпеки. Досягнення високих європейських соціальних стандартів неможливе без зміни ставлення людей до культури безпеки, екологічного світогляду, відповідальності за безпеку життя та здоров'я як особистого, так і суспільного.

Проблемні питання викладання дисциплін, пов'язаних 3 безпекою людини у ЗВО, набули особливої гостроти й актуальності. Події, які відбуваються в нашій країні останнім часом, викликають глибокі зміни в усіх сферах суспільного життя. Адже сьогодні в період активного зростання рівня технічних досягнень і збільшення кількості аварій та катастроф техногенного та екологічного характеру країна також має потребу у висококваліфікованих фахівцях 3 техногенної та екологічної безпеки для здійснення контролю за забезпеченням вимог державних стандартів, норм і правил з питань безпеки, за дотриманням вимог чинного законодавства у сфері цивільного захисту під час проектування, будівництва, реконструкції, технічного переоснащення та експлуатації будівель, споруд та інших об'єктів незалежно від форм власності й видів діяльності.

Одне $з$ провідних місць у даному аспекті посідають фахівці з охорони праці, професійна діяльність яких має інтеграційний характер, оскільки відноситься до складної групи нечисленних професій, що функціонують одночасно в кількох системах, а саме «людина-людина», «людина-техніка» та їх модифікації.

У зв'язку з цим зростає роль і відповідальність системи вищої освіти України за підготовку молоді 3 питань, які належать до галузі безпеки життєдіяльності, формування навичок безпечної поведінки. Тому одним із основних завдань ЗВО є розвиток у молодого покоління мислення і свідомого ставлення до безпечної поведінки, від чого буде залежати не лише особисте здоров'я, а й здоров'я та безпека оточуючих.

3 метою підвищення якісного рівня підготовки фахівців різних освітніх рівнів з питань охорони праці та практичної реалізації принципу пріоритетності охорони життя та здоров’я працівників наказом Міністерства освіти і науки України «Про організацію та вдосконалення навчання з питань охорони праці, 
безпеки життєдіяльності та цивільного захисту у ВНЗ України» від 21.10.2010 p. № 969/922/216 було впроваджено в навчальний процес вивчення студентами всіх закладів вищої освіти дисциплін «Безпека життєдіяльності», «Основи охорони праці», «Охорона праці в галузі», «Цивільний захист».

Дисципліни, пов'язані з безпекою людини, є важливими у підготовці майбутніх педагогів у цілому, та педагогів професійного навчання зокрема. Вони вивчаються 3 метою формування у майбутніх фахівців із вищою освітою необхідного в їхній подальшій професійній діяльності рівня знань і вмінь із правових та організаційних питань охорони праці, основ фізіології, гігієни праці, виробничої санітарії, безпеки процесів праці та пожежної безпеки, визначеного відповідними державними стандартами освіти.

Аналіз останніх досліджень і публікацій. Питанням викладання дисциплін, пов'язаних з безпекою людини у ЗВО України відповідно до вимог кредитно-модульної системи, присвячено працю Я. Семчук, О. Малишевської, Р. Борисюк (Семчук Я. М., Малишевська О. С., Борисюк Р. 3., 2010). Такими вченими як О. Запорожець, А. Русаловський, B. Заплатинський, Б. Халмурадов (Запорожець О. I., Русаловський А. В., Заплатинський В. М., Халмурадов Б. Д., 2007) проаналізовано головні нормативні документи, які регламентують порядок планування, викладання дисциплін, пов'язаних 3 безпекою людини. Питанням покращення підготовки студентів 3 питань охорони праці, безпеки життєдіяльності та цивільної оборони населення присвячені роботи інших авторів (В. Жидецький, 2002; С. Желібо, Н. Заверуха, В. Зацарний, 2010).

Метою статті $\epsilon$ аналіз сучасного стану проблем i нормативно-правових засад викладання безпекознавчих дисциплін у ЗВО України.

Виклад основного матеріалу. Під час вивчення дисциплін, пов'язаних з безпекою людини, чітко проглядається тісний взаємозв'язок наук (фізики, математики, хімії, біології тощо) та їх прикладних напрямків (технології виробництва, приладобудування, технологій, матеріалознавства, безпеки експлуатації та ін.), які детально дозволяють розкрити історію розвитку уявлень про безпечні методи праці та виробництва. 
Ефективність навчально-виховного процесу 3 безпекознавчих дисциплін, у першу чергу, залежить від вибору викладачем форм, методів і прийомів проведення занять. Викладач має бачити великі резерви використання в навчальному процесі сучасних досягнень науки і техніки, які поки що недостатньо ефективно використовуються в освіті. Зокрема, такий засіб діяльності, як комп'ютер, дозволяє достатньо повно врахувати початковий рівень пізнавальної діяльності студентів та їх індивідуальні особливості. На цій основі у закладі вищої освіти активно використовуються новітні інформаційно-комунікаційні технології, сучасні педагогічні технології.

У ситуації, що склалася, зрозумілим $є$ те, що кожна людина i, безперечно, людина 3 вищою освітою (педагог професійного навчання) повинна усвідомлювати важливість питань безпеки життєдіяльності людини. Підготовка студентів у рамках безпекознавчих дисциплін містить теоретичні питання, спрямовані передусім на формування світогляду, вироблення ідеології поведінки і забезпечує майбутніх фахівців важливим інструментом не лише щоденного безпечного контактування $з$ навколишнім світом, а й готує до безпечного виконання технологічних процесів різних рівнів складності, формує світогляд майбутнього фахівця, який у своєму звичайному житті повинен забезпечувати попередження розвитку надзвичайних ситуацій або зменшення наслідків від їх розвитку.

У зв'язку з перебудовою системи освіти України, удосконаленням навчального процесу в цілому, перед викладачами закладів вищої освіти виникає необхідність пошуку тих методів навчання, які б удосконалювали самостійну роботу студентів, забезпечували розвиток у них гнучкості мислення, ініціативності, пізнавальної активності, самостійності прийняття правильних рішень, творчого підходу до розв'язання проблемних ситуацій.

Однак сучасна система навчання 3 питань безпеки людини недосконала. Традиційне навчання, що проводиться на рівні інструктажу: ввідний, первинний, поточний, позаплановий, цільовий, які зіграли в свій час позитивну роль, 
на даному етапі потребує подальшого вдосконалення як за змістом, так і за організаційними формами навчання. Проблема вдосконалення сучасного змісту навчальних програм і планів стає актуальною особливо тепер, що пов’язано, насамперед, 3 постійним розвитком науково-технічного прогресу та інноваційних технологій сучасного виробництва, а розвиток останніх, у свою чергу, диктує нові небезпеки, з якими людина не стикалася і до тепер. Необхідність у проведенні таких досліджень очевидна (Інтегрована навчальна програма. Київ: Освіта України, 2005).

Розглянемо, наприклад, «Освітньо-професійну програму підготовки бакалавра за спеціальностями напряму «Професійна освіта», яка досліджена та схвалена представниками десятків навчальних закладів України, затверджена Міністром освіти і науки України. У цій програмі пункт «Безпека життєдіяльності» складається з трьох модулів (Чорна, Заєць, Нещадим, Слободян, 2012: 11-13): Модуль 1. «Охорона праці»; Модуль 2. «Безпека життєдіяльності»; Модуль 3. «Цивільний захист».

При детальному розгляді змісту цих модулів питання, 3 яких вони складаються, та їх послідовність є не зовсім зрозумілими. На жаль, це не єдиний приклад.

Свою педагогічну діяльність у ЗВО викладачі дисциплін циклу «Безпека життєдіяльності» будують на основі декількох документів:

1. Програми нормативної дисципліни «Безпека життєдіяльності» для вищих навчальних закладів освіти, затвердженої першим заступником Міністра освіти і науки України 04.12.98 р.;

2. Програми нормативної дисципліни «Основи охорони праці» для вищих навчальних закладів освіти, затвердженої першим заступником Міністра освіти i науки України 31.07.97 р., та програми підготовки спеціалістів та магістрів дисципліни «Цивільний захист» № 182/200 від 20 червня $1995 \mathrm{p}$.

Послідовність викладання цих дисциплін затверджена наказом Міносвіти України № 420 від 02.12.98 р. Викладання безпеки життєдіяльності доцільно зреалізувати на 1-2 курсі, але 
викладання на цьому курсі «Цивільного захисту» не є своєчасним, оскільки цей матеріал важко сприймається студентами, які ще не в повному обсязі засвоїли основні дисципліни своєї майбутньої професії. Тому викладання безпеки життєдіяльності, основ охорони праці та цивільного захисту повинно бути розташовано за семестрами. У контексті 3 методикою викладання та міжпредметними зв'язками найбільш правильно викладати курс «Безпека життєдіяльності» на третьому курсі у п’ятому або шостому семестрі. В наступному семестрі доречно ввести наступний курс «Основи охорони праці», а курс «Цивільний захист» - вже майбутнім магістрам або в останньому семестрі бакалаврату (Кобилянський, 2010: 246).

Відповідно до всього вищеперерахованого подаємо схему вивчення студентом ЗВО дисциплін (див. рис. 1) (Волненко, Богатов, Кулявець, Литвиненко, 2009: 56].

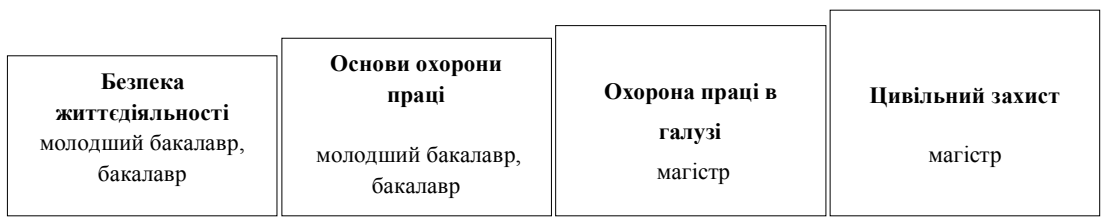

Рис. 1. Схема викладання дисциплін, пов'язаних 3 безпекою людини у 3 ВО

«Цивільний захист» $є$ обов’язковою дисципліною, яка включається в навчальні плани як нормативна і самостійна, та викладається на кафедрах охорони праці закладів вищої освіти. Відповідно до нормативних документів курс «Цивільний захист» повинен зберігати свою самостійність за будь-якої організаційної структури 3ВО та викладатися студентам освітньо-кваліфікаційного рівня «магістр» (Волненко, Богатов, Кулявець, Литвиненко, 2009: 57). Стає зрозумілим, що викладачам 3ВО, які здійснюють викладання курсу «Безпека життєдіяльності» студентам педагогічного напрямку необхідно зацікавлювати матеріалом, використовуючи міжпредметні зв 'язки зі спеціальними дисциплінами, що викликають інтерес та розвивають зацікавленість студентів. 
Вирішення сучасних проблем підготовки 3 безпеки життєдіяльності майбутніх педагогів професійного навчання необхідно насамперед спрямовувати на виконання таких завдань:

- Розробка додаткових освітніх програм 3 безпеки життєдіяльності, завдяки яким студент має можливість більш глибоко вивчити те чи інше природне, техногенне, соціально небезпечне явище, a, разом 3 цим, познайомитися 3 традиційними, новими і передовими способами захисту від існуючих небезпек і загроз.

- Удосконалення навчальних програм 3 безпеки життєдіяльності з урахуванням міжпредметних зв'язків 3 фаховими дисциплінами студента.

- Розробка нових підходів до самостійної роботи студентів, які передбачають різноманітність їі видів, і повною мірою забезпечують оволодіння умінням вирішувати професійні завдання, особливо «навчити» дій у випадку різних небезпек.

- Широке використання активних мультимедійних та інтерактивних форм навчання.

- Залучення до освітнього процесу практичних працівників - медиків, пожежних працівників, службовців 3 досвідом практичних дій, що підвищить інтереси і, як наслідок, якість знань і умінь.

- Розробка і створення навчальної літератури нового покоління (електронних посібників) 3 урахуванням особливостей навчання безпеки життєдіяльності студентів майбутніх педагогів (Волненко, Богатов, Кулявець, Литвиненко, 2009: 57).

- Також під час проведення будь-якого типу заняття 3 безпеки життєдіяльності доцільно використовувати комплекс методів навчання. Словесні (вербальні) або інформаційноповідомлювальні методи, - це методи словесної передачі та слухового сприйняття. До них належать: розповідь, пояснення, лекція, бесіда, диспут, семінар, робота з підручником.

За рівнем активності студентів і способом передачі інформації словесні методи можна поділити на дві групи: монологічні та діалогічні. Кожна група і кожний метод мають дидактико-методичні особливості. Зокрема, монологічні 
методи дають можливість повідомити студентам великий обсяг інформації, але їхня активність буде низькою. Тому для активізації пізнавальної діяльності студентів потрібно поєднувати моно- і діалогічну групи методів.

Словесні методи мають певні особливості. Наприклад, розповідь характеризується чіткістю, емоційністю і виразністю викладання, швидким темпом. Розповідь буває вступною, у вигляді пояснення, як підсумок. Пояснення - це поняття сутності закону, правил, що вивчаються; характеризується аналізом, висновком, формулою, побудовою схеми, графіку, уповільненим темпом з паузами.

Лекція - це логічне, послідовне повідомлення інформації, яке характеризується судженнями, висновками та підсумками. Для неї характерною $є$ наявність наукових відомостей. Розрізняють вступні, оглядові і підсумкові лекції. Лекція являється одночасно і формою, і методом навчання.

Бесіда - це діалогічний метод, який є досить складним і потребує належної підготовки. Бесіда буває: пояснювальна, евристична, узагальнювально-повторювальна, мотивуюча, інструктивно-методична, контролююча тощо.

Практичне заняття у вигляді семінару характеризується активним застосуванням знань, йому передує самостійне опрацювання студентами підручника та додаткових джерел. Семінар проводиться наприкінці вивчення теми або розділу i сприяє поглибленню та вдосконаленню знань, формуванню умінь і навичок, засвоєнню важливих тем. Робота 3 книгою розвиває у студентів інтелектуальні здібності, набуття навичок щодо навчання, сприяє розвитку правильної мови тощо.

Наочні методи використовують для полегшення сприймання матеріалу. До них відносять: ілюстрації (плакат), демонстрація (кінофільм, телепередача, комп'ютерний ролик, діюча модель, мультимедійна презентація), показ (на практичних заняттях), спостереження. Практичні методи призначені для формування інтелектуальних i загальнонаукових умінь та навичок студентів. Під час вивчення дисципліни можуть застосовуватись метод практичних робіт, дослідницька робота, моделювання, самостійна робота. 
Проблемно-пошукові методи активізують пізнавальну діяльність студентів, розвивають розумові здібності, стимулюють творчу діяльність, привчають до самостійності тощо. За ступенем проблемності їх можна розмістити так: репродуктивний (відтворювальний); частково-пошуковий (самостійна робота, узагальнення); евристична бесіда (дослідницький - лабораторні дослідження).

Логічні методи - використання методів індукції, дедукції, синтезу аналізу та порівняння, що сприяє кращому засвоєнню матеріалу, реалізації міжпредметних зв'язків, розвиває логічне мислення студентів тощо. Методи колективної розумової діяльності - мозкова атака, пізнавальна суперечка, навчальні дискусії, аналіз життєвих ситуацій та інше; їх використовують для того, щоб викликати інтерес, визначити колективну думку.

Імітаційні (ігрові) методи найбільше активізують процес навчання. Вони бувають індивідуальними і колективними (інтерактивними, від англ. interaction - взаємодія, вплив один на одного). До індивідуальних належать імітаційні вправи, аналіз конкретних ситуацій, до колективних - розігрування ролей, ігрове проектування, навчальні ділові ігри. Ці методи базуються на наслідуванні якогось процесу, події чи структури управління. Характеризуються вони наявністю імітаційної моделі. 3 дидактичного і методичного погляду навчальні ділові ігри, ігрове проектування можуть виступати у навчальному процесі як ігровий метод, засіб активізації, структурний елемент заняття або як форма організації навчальної діяльності студентів. Бінарні методи охоплюють методи викладання або керування, і методи уміння.

На заняттях з безпеки життєдіяльності використовуються як традиційні (загальні) методи навчання, так і спеціальні, які тісно пов'язані між собою і доповнюють один одного. Оптимальність добору відповідного методу навчання визначається характером діяльності та взаємовідносин «викладач - студент», глибиною й міцністю набутих знань, умінь і навичок, а також тим, якою мірою він викликає пізнавальну, емоційну й практичну активність студентів і формує у них мотивацію навчання (Величко, Царенко, 2008). 
Таким чином, ефективність викладання курсів, пов'язаних 3 безпекою людини, визначається методикою навчання, дидактичним i матеріальним забезпеченням предмету та вмінням викладача використовувати всі сучасні технології навчання для вирішення поставлених навчальновиховних завдань. Високий же професійний рівень фахівців 3 охорони праці дозволить роботодавцям знижувати травматизм до рівня економічно розвинених держав, що у свою чергу сприятиме позитивним змінам стану охорони праці .

Висновки та перспективи подальших досліджень. Дисципліни циклу «Безпека життєдіяльності», як система забезпечення та збереження життя, здоров'я і працездатності людини в процесі трудової діяльності $є$ найважливішою складовою професійної освіти, вони можуть бути реформовані, доповнені з урахуванням спеціалізації ЗВО або напряму підготовки студента. Але проблеми формування необхідних знань, умінь і навичок та підвищення їхньої якості з питань безпеки праці, проблеми удосконалення форм i методів викладання наук, пов'язаних з безпекою людини, проблеми впровадження та використання інформаційних, модульних, особистісно-орієнтованих технологій під час вивчення безпекознавчих дисциплін i на даний час залишаються нагальними.

При підготовці фахівців не слід недооцінювати роль безпекознавчих наук у формуванні професійних навичок майбутніх фахівців абсолютно всіх галузей. Крім того, у ЗВО слід дотримуватися саме ступеневої схеми вивчення зазначених дисциплін, оскільки усвідомлення необхідності набуття знань 3 «Цивільного захисту» та «Охорони праці в галузі» приходить до майбутніх фахівців лише після отримання базових знань у сфері безпеки життєдіяльності, набуття стійких уявлень про характер технологічних процесів та специфіку роботи підприємств, на яких у подальшому працюватимуть випускники.

Отже, підготовка майбутніх педагогів професійного навчання $з$ питань охорони праці має величезне значення для здійснення державної політики в галузі охорони праці. Навчальний курс «Безпека життєдіяльності» не повинен 
скорочуватися або об'єднуватися з іншими дисциплінами, тому що кількість небезпек, які загрожують сучасній людині, постійно збільшується. У нинішньому соціально-політичному становищі в країні таке скорочення годин, відведених на вивчення дисциплін, які дають студентам життєво необхідну інформацію щодо дій у разі виникнення небезпеки різного походження, можна розглядати як загрозу національній безпеці України в цілому. Необхідно творчо підходити до удосконалення підготовки випускників 3ВО, в тому числі використовуючи сучасний європейський досвід. Подальші дослідження теми повинні спрямовуватися на пошук i впровадження нових та сучасних оптимальних форм і методів навчального процесу 3 метою покращення практичної підготовки майбутніх педагогів професійного навчання у ЗВО, адже зараз важливим $є$ не тільки якість навчання, а й якість отриманих знань.

\section{ДЖЕРЕЛА ТА ЛІТЕРАТУРА}

1. Безпека життєдіяльності, цивільна оборона та охорона праці: Інтегрована навчальна програма. Київ: Освіта України, 2005. 24 c.

2. Величко С. П., Царенко І. Л. Методика викладання безпеки життєдіяльності: навчальний посібник. Київ: КНТ, 2008. 318 c.

3. Волненко Н. Б., Богатов О. І., Кулявець Ю. В., Литвиненко В. М. Щодо необхідності перегляду навчальних програм 3 дисципліни «Безпека життєдіяльності». Вісник Національного технічного університету «ХПI». 2009. № 9. C. 54-59

4. Желібо С. П., Заверуха Н. М., Зацарний В. В. Безпека життєдіяльності: навч. посіб. для студ. вищ. навч. закл.; За ред. Є. П. Желібо. 6-е вид. Київ: Каравела, 2010. 344 с.

5. Жидецький В. Ц. Основи охорони праці: підручник. Львів: Афіша, 2002. 320 с.

6. Запорожець О. I., Русаловський А. В., Заплатинський В. М., Халмурадов Б. Д. Питання державного регулювання викладання у ВНЗ дисциплін «Безпека життєдіяльності». Безпека життєдіяльності. 2007. № 11. С. 11-13. 
7. Кобилянський О. В. Вивчення безпеки життєдіяльності при підготовці бакалаврів економічного спрямування. Наукові записки ТНПУ ім. В. Гнатюка. Сер. Педагогіка. Тернопіль, 2010. № 1. С. 243-250.

8. Семчук Я. М., Малишевська О. С., Борисюк Р. 3. Впровадження Болонських декларацій у практику підготовки фахівців у сфері цивільного захисту. Безпека життєдіяльності. 2010. № 6. С. 18-20.

9. Чорна Т. М., Заєць В. А., Нещадим Л. П., Слободян О. П. Проблеми викладань циклу з питань безпеки життєдіяльності у вищих навчальних закладах. Безпека життєдіяльності. 2012. № 11. С. 11-13.

\section{REFERENCES}

1. Bezpeka zhyttyediyalnosti, tsyvilna oborona ta okhorona pratsi: Intehrovana navchalna prohrama (2005). [Life safety, civil defence and labour protection]. Kyiv: Osvita Ukrayiny. 24 [in Ukrainian].

2. Velychko, S. P.\& Tsarenko, I. L. (2008). Metodyka vykladannia bezpeky zhyttiediialnosti: navchalnyi posibnyk [Methods of teaching life safety]. Kyiv: KNT. 318 [in Ukrainian].

3. Volnenko, N. B. \& Bohatov, O. I. \& Kulyavets, Yu. V. \& Lytvynenko, V. M. (2009). Shchodo neobkhidnosti perehlyadu navchalnykh prohram z dystsypliny «Bezpeka zhyttyediyalnosti» [On the necessity of revision of curricula for the discipline «Life Safety»]. Visnyk Natsionalnoho tekhnichnoho universytetu «KhPI». № 9. 54-59 [in Ukrainian].

4. Zhelibo, Ye. P \& Zaverukha, N. M. \& Zatsarnyy V. V. (2010). Bezpeka zhyttyediyalnosti: navch. posib. dlya stud. vyshch. navch. zakl; Za red. Ye. P. Zhelibo [Life safety]. 6-e vyd. Kyiv: Karavela. 344 [in Ukrainian].

5. Zhydetskyy, V. Ts. (2002). Osnovy okhorony pratsi: pidruchnyk [Basics of labor protection]. Lviv: Afisha. 320 [in Ukrainian].

6. Zaporozhets, O. I. \& Rusalovckyy, A. V. \& Zaplatynskyy, V. M. \& Khalmuradov, B. D. (2007). Pytannya derzhavnoho rehulyuvannya vykladannya u VNZ dystsyplin «Bezpeka zhyttyediyal'nosti» [Questions of state regulation of instruction in 
higher education disciplines of «Safety»]. Bezpeka zhyttyediyalnosti № 11. 11- 13 [in Ukrainian].

7. Kobylyanskyy, O.V. (2010). Vyvchennya bezpeky zhyttyediyalnosti pry pidhotovtsi bakalavriv ekonomichnoho spryamuvannya [The Study of life safety in the preparation of bachelors of economic direction]. Naukovi zapysky TNPU im. V. Hnatyuka. Ser. Pedahohika. Ternopil. 1. 243-250 [in Ukrainian]. 8. Semchuk, Ya. M. \& Malyshevska, O. S. \& Borysyuk, R. Z. (2010). Vprovadzhennya Bolonskykh deklaratsiy u praktyku pidhotovky fakhivtsiv u sferi tsyvilnoho zakhystu [Introduction of Bologna declarations into the practice of training specialists in the field of civil protection]. Bezpeka zhyttyediyalnosti [Life safety], 2010. 6. 18-20 [in Ukrainian].

9. Chorna, T. M. \& Zayets, V. A. \& Neshchadym, L. P. \& Slobodyan, O. P. (2012). Problemy vykladan tsyklu z pytan bezpeky zhyttyediyalnosti u vyshchykh navchalnykh zakladakh [The Problem of prepodavanii cycle on issues of life safety in higher educational institutions]. Bezpeka zhyttyediyalnosti [Life safety], 11. 11-13 [in Ukrainian].

\section{АНОТАЦІЯ}

У статті висвітлюються актуальні питання щодо проблем викладання дисциплін, пов'язаних з безпекою людини y закладах вищсої освіти. Визначено, від чого залежить ефективність навчально-виховного прочесу з безпекознавчих дисциплін, на виконання яких завдань потрібно спрямовувати викладачів задля вирішення сучасних проблем підготовки $з$ безпеки життєдіяльності майбутніх педагогів професійного навчання. Виокремлено комплекс методів навчання, які дочиільно використовувати під час проведення будь-якого типу заняття з безпеки життєдіяльності.

Зроблено висновки, що цикл дисииплін «Безпека життєдіяльності» як система забезпечення та збереження життя є найважливішою складовою професійної освіти $i$ може бути реформована та доповнена з урахуванням спеціалізації закладів вищої освіти або напряму підготовки студентів. Окрім того, при підготовиі фахівців не слід недооиінювати роль безпекознавчих наук у формуванні 
професійних навичок майбутніх фахівців усіх галузей. У $3 В О$ доиільно дотримуватися саме ступеневої схеми вивчення циклу безпекознавчих дисцииплін та мати найвищий пріоритет, тому щзо безпека - $\epsilon$ важливою складовою життя людини, щзо гарантується Конституиією Украӥни. Запропоновано можливі шляхи усунення проблем.

У сучасних умовах посилення інтеграційних процесів 3 Свропейським Союзом та впровадження європейської системи неперервної освіти програми нормативних дисциилін $i$ відповідні освітньо-професійні програми повинні враховувати положення досконалої європейської системи нормативноправових актів з безпеки людини. Тому, розллядаючи проблеми викладання дисциплін, пов'язаних з безпекою людей, у процесі занять з предметів "Безпека життєдіяльності», "Основи охорони праці» та «Цивільний захист» необхідно передбачати пошук оптимальних форм $i$ методів навчально-виховного проиесу з реалізащіі міжпредметних зв'язків $i$ збільшення практичної підготовки на основі сучасної нормативної бази, розробки спеціальних технологій формування професійной компетентності фахівців усіх спрямувань, удосконалювати методики підготовки студентів за теоретичною та практичною складовими з изілеспрямованим формуванням у них фахової компетентності, а також постійно активізовувати професійне самовдосконалення студентів, щуо сприяє їх самоактуалізації, формуванню професійних потреб, мотивів та мотивацій.

Ключові слова: професійна освіта, охорона праці, методи, діяльність, студенти, фахівці, технології.

\section{АННОТАЦИЯ}

В статье освешуаются актуальные вопросы относительно проблем преподавания дисциплин, связанных с безопасностью человека, в учреждениях высшего образования. Определено, от чего зависит эффективность учебновоспитательного процесса по преподаванию ичикла дисичилин по безопасности жизнедеятельности, на выполнение каких задач нужно направлять преподавателей для решения современных проблем подготовки по этим учебным курсам 
будуших педагогов профессионального обучения. Выделен комплекс методов обучения, которые целесообразно использовать при проведении любого типа занятия по безопасности жизнедеятельности.

Сделаны выводы, что ичикл дисциилин «Безопасность жизнедеятельности» как система обеспечения и сохранения жизни является важнейшей составляющей профессионального образования и может быть реформирована и дополнена с учетом специализации высших учебных заведений или направления подготовки студентов. Кроме того, при подготовке специалистов не следует недооченивать роль наук, связанных с безопасностью, в формировании профессиональных навыков будущих специалистов всех отраслей. В выстих учебных заведениях целесообразно придерживаться именно ступенчатой схемь изучения цикла дисциилин по безопасности, и давать им высший приоритет, потому что безопасность является важной составляющей жизни человека, что гарантируется Конституцчией Украины. Предложень возможные пути устранения проблем.

В современных условиях усиления интеграџионных проиессов с Европейским Союзом и внедрения европейской системы непрерывного образования программы нормативных дисциплин и соответствуюшие образовательнопрофессиональные программы должны учитывать положения совершенной европейской системы нормативно-правовых актов по безопасности человека.

Поэтому, рассматривая проблемь преподавания дисциилин, связанных с безопасностью людей в процессе занятий по предметам «Безопасность жизнедеятельности», «Основь охраны труда» $и$ «Гражданская защчита», необходимо предусматривать поиск оптимальных форм и методов учебно-воспитательного прочесса по реализации межпредметных связей и увеличения практической подготовки на основе современной нормативной базы, разработки специальных технологий формирования профессиональной компетентности специалистов всех направлений, усовершенствовать методики подготовки 
студентов по теоретической и практической составляющих с изеленаправленным формированием у них профессиональной компетентности, а также активизировать профессиональное самосовершенствование студентов, что способствует их самоактуализации, формированию профессиональных потребностей, мотивов и мотивациий.

Ключевые слова: профессиональное образование, охрана труда, методы, деятельность, студенты, специиалисть, технологии.

Надійшла до редакиії: 04.01.2019 p. Прийнята до друку: 25.01.2019 p. 